can work with lassa fever virus sequences safely in bacteria. (Let me just say that I think lassa fever virus cloning in bacteria is a big no-no experiment, both here and in the United States, and it would take the direst national emergency to make me work with lassa fever virus, and I'd be very, very careful myself!)

But this is a paradox of the whole field-I put it to you-it sounds awful, but I think I must put it as strongly as that-I would work with the lassa fever virus in $E$. coli any day. I'd consider that to be my best guarantee of safety.

\title{
New diseases in new niches
}

\section{By Jonathan King}

6 RECOMBINANT DNA certainly represents a major breakthrough in our ability to study the organisation of the genetic material of higher organisms; and I should say that from the research point of view recombinant DNA technology can be employed safely. A1though in order to employ it safely you have to assess very carefully what's dangerous about it. But perhaps more relevant here is the new production technology, technology that will be used to manufacture commodities for sale. The transformation from research tools to production technology has proceeded far more rapidly than many scientists envisioned. Within a year or two in the United States Eli Lilly corporation expects to be producing human insulin through the growth of thousands of gallons of Escherichia coli containing human DNA sequences spliced into a bacterial plasmid.

Now the deployment of new production technologies has more often than not been associated with the generation of unfortunate side effects on the health and welfare of the human populationmost notably those employed at the point of production. I have here a few historical examples. For example the mechanisation of cotton textile manufacture resulted in a drastic increase in damage to the respiratory tract of the operatives (byssinosis or brown lung). Developments in the German chemical industry - such as the synthesis of the aniline dyes which were used to colour the textiles - entailed the production of potent bladder carcinigens-4-aminobiphenyl and $\beta$-naphthylamine.

Most of us can be reasonably assured that most of those chemical carcinogens that are already out there through previous mishandling will not reproduce and increase themselves in the environment. The risk is finite. In the case of bacteria we do have to worry that these organisms-or at least the genes that are linked to the plasmids within these bacteria-will move through the ecosystem, transfer for example from the debilitated strains to wild strains of bacteria, and get into strains which perhaps are well-adapted in a particular niche out there. And then we won't be able to clean them up, for you can't remove, for example, $E$. coli from the ecosystem. It is an intimate part of mammalian life.

Now at this point I wish to clarify and punctuate a very crucial aspect of risk assessment. In trying to assess hazard we must consider what would be the properties, for example, of a wild strain of $E$. coli-even an epidemic strain of $E$. coli-expressing, for example, the human gene for insulin. Now some in the audience will heatedly reply-or they would if I were at home- -"but they'll never get into wild strains, they're in debilitated strains, you've got nothing to worry about, you're raising a false spectre". This is of course putting the cart before the horse. The only way that hybrid DNA will be contained, is if people understand that if it not contained there may be problems.

Thus in assessing the risk of cotton dust, we do not examine the effect of cotton fibres on human skin; we examine the effect of cotton fibres on human lungs. Of course, manufacturers in the industry often say "no that's wrong, because the cotton fibres will never get into the workers' lungs". But we know that that it is only if people understand acutely what will happen if those fibres do get inside the lung, that action is taken. And knowledge in the past has not been sufficient, it's taken much more action than knowledge.

I must ask: where have infectious diseases come from? After all if I'm going to make a feasible case that there is something to worry about in generating a new human disease, I'm behoven to explore the question of the generation of old ones.

The virulent form of cholera Vibrio infection, with characteristic rice-water stools, was first reported in the highly densely populated and unsanitary city of Calcutta in 1817. From there it was carried by the British navy to the newly emerging industrial areas in the north-west of England. Manchester in this period was rapidly converting from cottage production of cotton textiles to full-scale factory production. The workers needed to man the mills were either forced off agricultural holdings or one way or another brought into the
I think you must ponder these things because at first sight they appear totally paradoxical. That is because we have not thought out the hazards directly. I think we have not solved all the problems, and I think there is an enormous amount of work that still remains to be done. 9 city, and essentially forced to live in housing not of their own design. The nature of this housing is quite well documented-miserably crowded, very little light or ventilation, no sanitation, no proper water supply, no means of disposing of waste, thus garbage and excrement polluting the waters used for drinking and washing and food preparation.

Cholera thrived in these industrial districts because these organisms multiply in the intestine, where they elaborate a toxin; and this toxin binds and penetrates the cells of the intestine, and inactivates a protein of the intestinal cells which is needed in protein synthesis. The organism however goes out in the faeces, and if you live in an area with a contaminated water supply and you drink that stuff-boom -you get cholera.

The growth of textile manufacture in the north of England, and also in the midlands, gave rise to many other niches. One of them was damaged lungs from cotton fibres, particularly among operatives of the carding and combing room, where the cotton is taken from the boll to the fibre. These individuals were unusually susceptible to tuberculosis and pneumonia infections, since with the primary barrier of the lung and respiratory tract broken, these organisms move down the respiratory tree and eventually get down to the alveoli of the lung, when you have profound tuberculosis and pneumonia.

Given the conditions that they lived in at home, where there was very very close person-to-person contact, contaminated food, no pasteurisation, etc, there were once again created special conditions for these organisms to 
thrive. Remember also that in this period also children were employed in the mills working 12 to 14 hours a day, malnourished, lacking sunlight, they were hypersusceptible to tuberculosis and related infections. The extraordinary mortality rates among children at that time are due in large part to that.

Thus this is a situation in which technological changes created conditions, both in the factory and at home, in which particular strains of pneumococcus, tuberculosis, and cholera could thrive. Fortunately these conditions do not exist any longer. Over the last 150 years through a kind of alliance between progressive scientists and public health people, and-very importantly-the labour movement, which played a primary role in the fight for decent sanitation and public health, we have reached conditions where water supplies and proper sewers are considered social necessities rather than individual privileges, decent food is available to most people.

I have never thought that the dangers of recombinant DNA research had to do with the generation of a spreading epidemic-some organism that would spread throughout the world. Those conditions don't exist now. It's not the nature of mortality from infectious disease. In fact over the past 30 years, the development and the production of antibiotics has created a possibility where even the rare emergence of some of these organisms can be controlled by antibiotics.

On the other hand, recently we've witnessed the ironic side-effects of the mis-use of the antibiotic technology. The Swann committee dealt with the problem here in the UK. In the United States, though we may have had a Swan committee, it came down on the other side, and we still introduce massive amounts of antibiotics routinely into the feed of chickens, cattle, and hogs, and thus into the general environment.

As a result there is intense selection throughout most industralised countries for organisms bearing resistance to antibiotics. And this very often is coded by plasmids, the very plasmids that are the parents of those plasmids that are used in the recombinant DNA technology. The other problem of course is hospitals in private practice where antibiotics are tremendously overused, once again creating niches. For example a little pool of water on a sink that's not cleaned up as often as it should be, is a niche where bacteria can thrive only if they contain plasmids conferring resistance to antibiotics.

Now let's switch to the current period of time and ask, in industrialised nations, what kind of problems do we have from infectious diseases? (And again by 'infectious' I don't mean person-to-person spread-I mean parasitic organisms.) I've just looked briefly at North Carolina and New Jersey in the United States. In North Carolina there are still a great many cotton mills, and byssinosis is still present at a very high rate. (That's because in the United States until very recently brown lung was not recognised as a disease. At least no doctor was willing to testify in court that a cotton worker had lost lung function from that disease.) Also the mechanisation of the cotton industry, which involves grinding up the bracts around the boll into a very fine dust-and it is the bracts that are the primary causative agents of lung disease--increases the problems of the cardroom workers with byssinosis.

So these people occasionally go to the hospital, when they get older, and they are diagnosed as having anticema or some obstructive problem in the bronchi and there is some surgical procedure or some unconventional procedure. What happens then, and so much so that it's a major health problem in the United States (and I believe also in England), is they pick up a hospital infection, a hospital pneumonia, because the primary physical barrier has been breached. A very high percentage of time these infections are due to $E$. coli, a strain that in the old days was never ever thought of as a pathogen. $E$. coli is a laboratory bug, it's the medical students' bacterium, it's something we don't have to worry about.

In Essex county in New Jersey workers still get bladder cancer at ten times the national average. (New Jersey also has the highest concentration of the dye industry.) These people occasionally go to hospitals (if they have health insurance-in the United States that's only a quarter of the population), and maybe they get chemotherapy for their bladder cancer. And they are immunosuppressed. And as a result of this they pick up hospital acquired infections also very often $E$. coli.

Now these infections are not of the spreading epidemic type. It's a different thing; it's a point source; it's more like the bladder carcinogens coming out of the aniline dye industry. There's a place where the organisms are survivingthere's some reservoir-and then somebody comes in who's debilitated or weakened and they pick up the infection.

I don't mean to scare you-I'm now talking about ordinary antibiotic resistant $E$. coli infections-not recombinant DNA-but just to give you a sense of the extent of this I calculate that at present in the United States each year
90,000 individuals suffer surgical wound infections with $E$. coli with 2,700 associated deaths; 40,000 individuals contract $E$. coli pneumonia infections, with 10,0000 associated deaths; and 17,000 people contract $E$. coli bloodstream infections with 4,000 associated deaths. Of course the primary infection is urinary tract infection-about 300,000 cases in the United States, primarily in women.

Now these people are weakenedbut that's what happens when you go to the hospital, you're in an automobile accident, or maybe a little baby and your immune system hasn't fully developed; we have a right to be weakened, there's nothing wrong with being weakened. In this period of history the people who get bacterial infections are a different population from those who

"The only way that hybrid
DNA will be contained is if
people understand that if it is
not contained there may be
problems"

got bacterial infections 200 years ago.

I want to emphasise that one of the problems with these infections is that they carry plasmids specifying antibiotic resistance. And so when the person gets infected (1) the person's already weak; (2) if it's a bloodstream infection it's hard to treat; and (3) the plasmids are specifying antibiotic resistance. The organisms don't necessarily spread through the environment but the plasmids certainly spread from strain to strain. Thus you don't have to pick up a new bug-you pick up a new plasmid.

I mentioned child mortality in the $1800 \mathrm{~s}$ in Manchester. We don't have that problem now; child mortality has a different character, it's not typhus or typhoid or dysentery; but we do have premature babies who are kept alive in conditions where in the old days they would have died. In the United States these premature infants get a very high rate of meningitis infections-and this is meningitis from $E$. coli. It's a nasty infection, 40 to $80 \%$ mortality, and the children who survive have neurological and behavioural abnormalities. The strain of bacterium which causes this $-E$. coli with a $\mathrm{K} 1$ antigen-is not a particularly virulent strain of $E$. coli, it's in the mothers, it's out there in the normal population; but if it gets into the meninges, into the spinal cord tissue of a premature infant, then you get a very nasty infection. Again it's special conditions.

Now, let's go back to the older view and say what kind of conditions make bacteria nasty with respect to human disease. Well, we have a few cases: 
synthesis of a toxin, would be one case, synthesis of a protein increasing the colonising capacity-the ability to stick somewhere-and resistance to antibiotic therapy. The last one I've covered. Cholera, let me remind you, makes a protein that binds to human cells. Diphtheria toxin-the classic case - comes from infection by a phage, not a plasmid, which specifies a protein that's exported outside the cell: that's the thing that makes you sick.

Now I'd like to note two general features of pathogenesis. First, many of these proteins that are associated with the pathogenic character of historically studied bacteria are coded by plasmids; and the transmission from cell to cell of these plasmids is a major medical problem. (It was in the past, and is presently.) Secondly, the feature of many of these toxins is that they have the property of interacting with mammalian cells. You know most proteins in bacteria don't interact with me. They interact with each other. If you want to get a protein that will interact tightly with me, you go to my cells. Go to my kidney cells, and you'll find many many proteins that interact with kidney cells for example, those proteins on the surface of one kidney cell responsible for sticking to the other kidney cell so that I have a kidney.

A number of people in trying to counter the question of the hazards of recombinant DNA research have said human DNA has been getting into bacteria time and time again all through human history. And it has even been proposed explicitly by the very notable American cell biologist Lewis Thomas, though he was making the opposite argument, that some of the diseases I've talked about, like cholera toxin, that the origin of that protein may have been a rare recombinational event, at some time in history, in which a mammalian gene for protein got into bacteria, and that's the way you got a protein that interacts with mammalian cells. So the model here is that when that happens it can be a very unfortunate event.

Now let me move to the question of whether there is really a serious hazard, or how many hairline cracks are there in Sydney Brenner's aircraft engine, in the introduction of mammalian genes into enteric bacteria? I'm sorry I'm forced into the thing that Sydney describes as example and counterexample, but the risk-assessment research hasn't been done-in the United States it has been blocked, and in my estimation it's been blocked because some risk is going to emerge. It's very unfortunate that one's forced into somewhat extreme examples, because the primary data, which might refute some of these, is not available.
We have genes which increase the pathogenicity of the host organism in the niches already occupied-that's one possibility; the second is a gene that makes a protein that allows the bug to grow in a place it didn't beforecolonise a new place, stick to an organ it didn't before-for example for $E$. coli to colonise the upper respiratory tract, which it doesn't right now; and the third is a more subtle effect, something I've been very concerned with : interfering with the immune response of the host organism.

What about insulin? I don't know what would happen if a newborn infant picked up an $E$. coli meningitis infection and that bacterium was spooing out human insulin; but it seems to me there's every reason to be concerned. And I can't tell you what would happen if the genes for somatostatin, another potent hormone which has been cloned for commercial manufacture, were to be put into a wild strain of $E$. coli; again there's every reason to be concerned. And any endocrinologist not in the pay of the company producing it would have to give pause to the uncontained DNA.

In terms of a new niche, well certainly one of the classes of proteins that people want to study-I'd like to study it myself-is the class of proteins in human cells that allows one cell to stick to another. It's very important in the area of cancer research: how does a cell know when to stop dividing? One kind of DNA that will be cloned is the DNA that makes proteins of the cell surface. So people will be isolating bacteria that express in their surface a protein that involves binding to mammalian cells. There's every reason to think that that might, (though it may not), increase the pathogenicity of the wrong strain of bacteria.

Dealing with the immune systemthat's a little more complicated. I have submitted a paper on that to the Journal of Infectious Disease called "Recombinant DNA and autoimmune disease" which deals with a model of rheumatic fever, where you get a streptococcal infection, a sore throat, that bacteria shows a protein that looks like your heart protein, your body makes antibody against the bacteria, you get over the bacterial infection, and the circulating antibody attacks your own heart protein, and you get rheumatic complications. Well imagine for example an $E$. coli infection with a protein of the synovial membrane of the elbow. You are circulating antibody against the elbow. That is one of the established models of arthritis: antibodies attacking your own joints.

Now, in conclusion, the hazards of introducing an extraordinarily immense pool of genetic information into wild strains of microorganisms are serious; every effort must be made to see that the genes stay within the debilitated strains; and that these debilitated strains stay within the laboratory. Now this is going to require absolutely the fullest participation of laboratory workers and production workers. And you are not going to be able to do it without strong union participation.

In the area of recombinant DNA technology, the way you know that these organisms are staying in the safe strains, staying in the strains in which they can be handled usefully from a research point of view and perhaps from a production point of view, is to make sure that laboratory workers are protected. If you can ensure that laboratory workers don't pick up these strains whether in their nasopharyngeal passages, or in a cut, or in a urinary tract infection, then you know they are not getting out into the population. The only way we know that can happen is if that sector of the population is fully involved in the safety standards.

Let me close with the fact that I think that just as in the area of occupational carcinogenesis, of black lung, of brown lung, the protection of people from disease involves a tight alliance between essentially progressive scientists and public health people-people who put that as their primary goal-and the trade union movement. That same alliance is the one that's needed with this new technology, and with many of the other new technologiesand more so now than in the past.

Furthermore that has to happen at the international level; because a smali sector of the scientific population which is disturbed by this control, which is disturbed by having technicians having a say in the decisions, flies around to international conferences to figure out how to get out of the guidelines, how to weaken the guidelines, how to avoid having trade union participation, and it can be very important that people like ASTMS make contact, for example, with groups in the United States, the oil, chemical, and atomic workers, the French unions, the German unions, the Belgian unions, who represent the same sector of the population, not only to protect themselves but to make sure that in the long run that we're all protected and that the benefits of this new technologywhich do exist, and I do believe in them -are realised.

My last point is: don't trust the NIH. Sydney Brenner was right that a better precedent has been established here than has been established in the United States. A fortune is going to be made from the cloning of insulin in bacteria. Four million doses are sold three times a week in the United States. They are not going to sell that insulin cheap; they are going to sell it expen- 
sive, because it's human insulin. They are going to produce it cheap. That is a very very powerful force behind the scenes, but it penetrates the scientific deliberations. So that in the United States we have scientists who in their public statements say "I'm only interested in the increase of human knowledge", while at the same time they have engaged lawyers to dissociate themselves from NIH funding, and get private funding, so that they can take out the patents.

Now we don't have a law in the United States that keeps anybody from introducing any gene into an epidemic strain of $E$. coli or salmonella or Shigella; and there are forces in that direction because of patents. If somebody else has a patent on making insulin in $E$. coli and you recognise that market what do you do? Take two of the venture capital corporations in the United States, Genentech and Cetus Corporation, both in California; the one has backing from International Nickel and the other from Standard Oil of Indiana. Their front men may be research scientists who say "we are only interested in the expansion of human knowledge", but the background there is very different.

\section{ASTMS plans to radicalise university and health service research}

\section{Sheila McKechnie talks to Robert Walgate}

The Association of Scientific, Technical, and Managerial Staffs (ASTMS), which called a meeting on genetic engineering last Friday, has its eye on health and safety in university laboratories. Laboratories in the health service are not left out either. "Freedom of research," says ASTMS health and safety officer Sheila McKechnie, "means whatever anybody wants it to mean at the time. And in the academic context it means that academics don't want to accept either social criteria for their decisions or an input from trades unions.

"If we've got standards of safety in GMAG laboratories it does seem to us that we should use GMAG as a comparison for work with dangerous pathogens; and if that is causing confusion in certain people's minds, then that's unfortunate, but when you talk about laboratory control and labora- tory safety we are looking to the GMAG model of containment for lots of other areas.

"You've got to remember that prior to 1974 [the date of enactment of the Health and Safety at Work Act] there were no legal standards which applied to the vast number of laboratories in which our members work-which is private research laboratories, public research laboratories, university laboratories, and National Health Service laboratories. Now you might say it's a very weak trade union argument to say that when you get a law you start doing something about it; but in fact it's a pattern of a great deal of trade union activity that when you get a law which protects in a minimum way the trade union movement, which hasn't previously seen it as an area for bargaining to be done in, sees a new impetus and sees the law as a minimum and begins to negotiate in that field.

"Laboratories in industry are more hygenic than the university or hospital laboratories. There's not the kind of scrimping on safety equipment that there is in a lot of hospital laboratories. They are probably more aware of their economic liability if anything goes wrong.

"The problem is the decision-making structure for the allocation of safety money. If unions like ASTMS push for grants from central government to improve laboratories, we would also want some control over how that money was spent. And there is almost total resistance to ASTMS having any say in both the amount and the allocation of that money. The problem in the universities is the anachronistic authority structure within those institutions; heads of departments in universities really are the last bastion of unilateral management prerogative. That is not the way that private companies work any more: they've been forced to recognise trades unions and work with them."
'REcombinant DNA' means different things to different people. Although it is now almost universally associated with the techniques of in vitro genetic manipulation, confusion can still arise when the term is loosely applied. (As in some comments on the cause of the recent case of smallpox in Birmingham.) For the products of 'old-fashioned' recombinationthe natural reshuffing of genes to produce bacteria, viruses, animals and men with a novel genetic make-up-are also recombinant DNAs.

So far there a few statutory controls on work with natural recombinants, even when it involves bacteria and viruses that can cause disease in man. But each experiment in which a recombinant organism is produced using the in vitro techniques of gene manipulation developed by molecular biologists come under the scrutiny of the Genetic Manipulation Advisory Group whose recommendations about the conditions in which the experiment should be carried out, are legally backed up by the Health and Safety Executive.

This has led to the paradox that experiments arriving at the same end-product can be carried out freely when the end is to be accomplished by natural recombination but come under scrutiny when in vitro recombinant techniques are to be used, and emphasises the difficulties in pro-

\section{Recombination: old and new}

ducing a logical and consistent set of guidelines for work in vitro recombinant DNAs.

Recombinant bacteria can arise naturally in a variety of different ways:

- Certain bacteria directly exchange their chromosomal DNA with members of their own species or with close relatives.

- Infection with particular bacterial viruses which can pick up pieces of bacterial DNA and pass these on to the next bacterium they infect can also produce a recombinant organism.

- Infection with certain bacterial viruses itself can dramatically change the nature of some bacteria. The ability to produce lethal toxins such as botulinum toxin and diphtheria toxin is conferred on the appropriate bacteria by infection with bacterial viruses which become integrated into the bacterial chromosome.

- Plasmids which can be transferred between quite distantly related bacterial species can transmit the genes for antibiotic resistance.

- Viruses can also exchange genetic material between similar or closely related types. Hybrid trains of inffuenza virus, herpes and smallpox, for example, all arise naturally from mixed infections or in mixed laboratory cultures of two or more different strains.

So-called 'in vitro recombinant DNA work' or 'genetic manipulation', specifically deals with work in which DNA from one organism is deliberately extracted, chopped up into manageable fragments with restriction enzymes and the resulting fragments spliced enzymatically into an appropriate plasmid or virus. This can then be introduced into the required recipient cell, whether bacterial, ycast or mammalian cell. The techniques of the molecular biologist can produce organisms that could have arisen naturally, but in addition they can also produce combinations that could not have arisen naturally. However, all in vitro recombinant experiments, whatever their outcome, are subject to GMAG controls in the UK and to the NIH guidelines in the USA.

A further twist to the story was provided earlier this year when American molecular biologists showed that in certain conditions, bacteria were quite capable of carrying out the 'in vitro' techniques themselves, using their own restriction enzymes to cut and splice foreign DNA into their own genetic material.

Eleanor Lawrence 